\title{
Opportunity Identification and Evaluation in Franchisee Business Start-ups
}

\author{
Maureen Brookes ${ }^{\mathrm{a}}$, Levent Altinay ${ }^{\mathrm{a}}$, Xuan Lorna WANG ${ }^{\mathrm{b} *}$, Ruth Yeung ${ }^{\mathrm{c}}$ \\ ${ }^{a}$ Oxford Brookes University, Oxford \\ ${ }^{\mathrm{b}}$ University of West London, London, W5 5RF, UK; \\ ${ }^{\mathrm{c}}$ Institute for Tourism Studies, Macau
}

\begin{abstract}
Purpose: This paper examines franchisees' business start-ups from an entrepreneurial perspective, adopting a process representative of entrepreneurship to examine opportunity identification and evaluation by franchisees and to analyse factors that influence this process.
\end{abstract}

Design/Methodology: A qualitative study was employed and data collected using semistructured interviews with a sample of service industry franchisees in Macau.

Findings: The study identifies that social networks play a key role in opportunity identification and that franchisees' goals influence the criteria used and information search activities undertaken while evaluating franchise opportunities.

Research implications: The study makes two contributions to franchise literature. It identifies that social networks can serve as substitutes for lack of prior knowledge in franchise opportunity identification. It also identifies the interrelated nature of franchisees' goals based on the activities and criteria used to evaluate franchise opportunities, and the importance of relational criteria when franchisees lack prior industry knowledge. It therefore also contributes to franchise/entrepreneurship literature by identifying the interrelated nature of the factors contributing to the dynamics of franchise chain growth.

Practical implications: Franchisors should explore how to better use franchisees' social networks and identify the longer-term goals of prospective franchisees to support market penetration and franchise chain growth. Franchisees are advised to use independent information sources to evaluate franchise opportunities using goal-informed objectives and demand and relational criteria.

Originality: The study presents a more comprehensive understanding of franchisees' decisionmaking process when joining franchise chains by identifying the activities undertaken and criteria used to identify and evaluate franchise opportunities.

Keywords: Franchisees, entrepreneurs, opportunity identification and evaluation, business start-up, social networks, guanxi

\section{*Corresponding author}

Tel.: +442082312323

email: lorna.wang@uwl.ac.uk 


\section{Introduction}

Franchising is variously described in service management literature as a business format, market entry mode, and distribution channel. However conceptualised, within service industries, franchising - business format franchising in particular - continues to grow in popularity (Gillis et al., 2011) and now exists in over 160 countries worldwide (IFA, 2011). Franchising plays an important role in the growth of global entrepreneurship (Chirico et al., 2011) and the creation of entrepreneurial wealth (Croonen and Brand, 2013), contributing value to national and global economies (Grunhagen et al., 2012). In an effort to understand the factors that contribute to both franchise and entrepreneurial growth, a developing stream of research now addresses the franchise/entrepreneurial interface. However, research that examines franchisee business start-ups from an entrepreneurial perspective is scarce, despite the potential contribution of such research to this understanding.

In business format franchising, a franchisor develops a brand concept, sells franchisees the rights and know-how to operate branded units, and provides operational, technical, and marketing support for a contractually determined period (Paswan and Witmann, 2009). Realising the economic benefits of franchising, therefore, is partially dependent on selling units to new or incumbent franchisees to achieve chain growth (Lucia-Palacios et al., 2014). Researchers have examined franchisees' motivation to join franchise chains (Knight, 1986; Peterson and Dant, 1990; Stanworth and Kaufmann, 1996; Weaven and Frazer, 2006; Bennet et al., 2010); their decision-making processes (Guillox et al., 2004; Doherty, 2009; Altinay et al., 2013); and how franchisors can signal value to prospective franchisees (Grunhagen and Dorsch, 2003; Harmon and Griffiths, 2008; Michael and Combs, 2008; Grace and Weavin, 2011; Lucia-Palacios et al., 2014). While these franchise studies have contributed to our understanding of individual elements of franchisee start-ups, examining a start-up as an 
entrepreneurial process will arguably enable a more comprehensive understanding of the factors that contribute to franchise chain growth. As a process, entrepreneurship focusses on the activities undertaken to identify, evaluate, and pursue opportunities (Shane and Venkataram 2000). Opportunities are core ingredients of the entrepreneurial process and generate economic value (Baron, 2006), but franchise researchers have tended to view opportunities negatively from an agency perspective (Barthelemy, 2008; Gillis et al., 2011; Silkoset, 2013). By examining opportunities from an entrepreneurial perspective, this study calls for further research to contribute to our understanding of the dynamics of franchise chain growth (Grewel et al., 2011).

This paper, therefore, examines the franchisee business start-up as an entrepreneurial process. Specifically, it seeks to identify and analyse the factors that influence franchisees' identification and evaluation of franchise opportunities. This paper adopts Shane's (2012) definition of opportunities as comprising the creation of new firms either through market mechanisms or by individuals in existing firms. It is, therefore, a suitable platform to examine entrepreneurial opportunities for franchisees as they seek to establish new firms in their own right, yet firms that are part of a franchise chain. Macau, a Special Administrative Region (SAR) of China, was chosen for the research, given the recent growth of franchising in Macau and in China (Grunhagen et al., 2012).

This study contributes to our understanding of franchise literature in two ways. First, it identifies how social networks can serve as substitutes to franchisees' lack prior knowledge in opportunity identification. While previous service management literature has identified the importance of relationship development in franchise chains (Lucia-Palacios et al., 2014), the role of social networks, and guanxi in particular, in facilitating the start of this relationship has 
been largely overlooked. Second, it reveals the influence of franchisees' goals on both the criteria used and on the information search activities undertaken in evaluating opportunities. It thus makes an additional contribution to franchise/entrepreneurship literature by identifying the interrelated nature of these factors, which are integral to the dynamics of franchise chain growth.

The paper begins with a review of the current franchise/entrepreneurship literature to identify research gaps before drawing on the entrepreneurship literature to frame the study's research questions. The qualitative research design and the findings are presented next. The conclusions highlight the implications of the findings for both franchisors and franchisees, the study's limitations, and future research directions.

\section{The franchisee/entrepreneur interface}

As franchisors develop a franchise concept after recognising a business opportunity and undertake risks to exploit that concept through franchisees (Michel, 2003; Clarkin and Rosa, 2005), they are generally considered entrepreneurs. In order to minimise risks, ensure brand uniformity, and protect brand reputation, franchise contracts frequently reflect high levels of standardisation and codification (Hoy, 2008). Accordingly, some researchers argue that these contracts prohibit entrepreneurial activity by the franchisee, declaring franchisees the 'antithesis of entrepreneurs' (Clarkin and Rosa, 2005:305). Research that supports this argument has examined franchisees' traits relative to those of independent entrepreneurs. Early studies revealed that franchisees exhibit less self-reliance, motivation (Knight, 1984), initiation, and autonomy (Withane, 1991) than independent entrepreneurs. Franchisees were subsequently found to have less prior experience and confidence in their skills and abilities (Sardy and Alon, 2007), possess lower quality skills (Williams, 1999), and lack expertise in 
risk-taking, opportunity recognition, and assessment of new ventures (Seawright et al., 2011). The desire to reduce risk has also been identified as influential in franchise purchase decisions (Withane, 1991; Brookes and Altinay, 2011).

However, other researchers argue that franchisees are entrepreneurial; their risk-taking behaviour has been identified in their pursuit of profit (Kaufmann and Dant, 1999) as well as in relation to franchisor failure (Michael and Combs, 2008) and franchisor support (Clarkin and Rosa, 2005). This has particularly been studied in the context of uncertain markets (Grewel et al., 2011) or international markets (Chen, 2010). Franchisees are frequently reported as the source of innovation (Combs and Ketchen, 2003; Grewel et al., 2011), using their knowledge of local markets (Gillis et al., 2011) to make appropriate adaptations (Kaufmann and Dant, 1999) and maximise performance (Combs et al., 2011; Dada and Watson, 2013). Merrilees and Frazer's (2006) Australian study suggests that this might be a result of franchisees' tendency to view setbacks as opportunities rather than as problems.

Researchers investigating franchisees' motivation to join franchise chains identify that greater independence or the ability to be your own boss is a key motivator for current franchisees (Knight, 1986; Peterson and Dant, 1990; Weaven and Frazer, 2006) and prospective franchisees (Stanworth and Kaufmann, 1996; Guillox et al., 2004; Bennet et al., 2010). However, other studies reveal that franchisees without previous self-employment experience attach more importance to the motivation for independence (Stanworth and Kaufmann, 1996) or that franchisees' motivations are similar to independent entrepreneurs (Davies et al., 2011). Grunhagen and Mittelstaidt (2005) advise that franchisees particularly seek fulfilment of entrepreneurial goals when they grow their number of franchised units sequentially. The 
difficulty in determining a homogenous set of franchisee motivations has therefore been recognised (Peterson and Dant, 1990; Weaven and Frazer, 2006).

As these studies have predominantly examined franchisees relative to independent entrepreneurs, it is perhaps not surprising that research findings are mixed. Even researchers who adopt a compromise position, arguing that franchising creates an entrepreneurial partnership (Davies et al., 2011; Grewel et al., 2011) or unique entrepreneurial structure (Meek et al., 2011) and franchisees are a distinct type of entrepreneur (Combs et al., 2011), do so on a comparative basis.

Research undertaken at the chain level has also yielded mixed results. While some debate whether entrepreneurial orientation (EO) and its dimensions of risk-taking, proactiveness, and innovativeness (Wales et al., 2013) have any potential in franchise chains, given the need for brand uniformity (Maritz and Nieman, 2006), Dada and Watson (2013) provide empirical evidence of the positive impact of franchisees' EO on chain performance. Opinions on franchisees being entrepreneurs therefore remain divided (Hoy, 2008), yet there is empirical evidence that franchisees are entrepreneurial, at least to some extent. As entrepreneurs, however, there remains a gap in our understanding of the activities franchisees undertake in the identification and evaluation of franchise opportunities. Given the potential impact these combined activities have on franchise chain growth, developing this understanding is arguably important. The following section, therefore, explores these activities within the entrepreneurship literature. 


\section{The process of entrepreneurship}

Entrepreneurial behaviour and the entrepreneurial process and are argued to provide important research directions for entrepreneurship (Gartner et al., 2010). Although different models of the entrepreneurship process have been developed (Moroz and Hindle, 2012), at a minimum, these comprise the identification, evaluation, and exploitation of opportunities (Shane, 2000). As franchisees exploit opportunities by joining chains, this research focusses on opportunity identification and evaluation and the factors that influence these activities.

\section{Opportunity identification}

Opportunities are 'those situations in which new goods, services, raw materials, and organizing methods can be introduced and sold for greater than their cost of production' (Shane and Venkataraman, 2000:220), although a profit is not guaranteed (Shane, 2012). Opportunities are alternatively considered to emerge through environmental dynamics and be discovered, or be created through entrepreneurs' perceptions and interactions with the environment (Shane and Venkataraman, 2000). However, some researchers argue that opportunities can be made as well as found (Dutta and Crossan, 2005; Venkataraman et al., 2012). Opportunities are variously argued to require the discovery of new means-end resource relationships (Shane and Venkataraman, 2000) or fundamentally new or slightly modified resource recombinations in new or less-than-saturated markets (Shane, 2012). They have also been categorised as innovative, incremental, or imitative (Gaglio and Katz, 2001); as either value-sought (from customers' perspectives) or value-creation (arising from underemployed resources) (Ardichvili et al., 2003); or as tacit and hard-to-articulate; or codified and well-documented (Smith et al., 2009). Given these different classifications, it is not surprising that Hansen et al. (2011) identified a great deal of fragmentation in defining and operationalising opportunities as a research construct, despite their fundamental role in the entrepreneurial process (Baron, 2006). 
Three interrelated factors have been shown to influence opportunity identification: prior knowledge, cognitive ability, and information search (Corbett, 2005; Baron, 2006). Through an in-depth case study, Shane (2000) identified that prior knowledge of markets, ways to serve them, and identification of customer problems are important. Prior knowledge that is complementary to the new information triggers an entrepreneurial conjecture (Shane, 2000), enabling individuals to connect the dots between changes in the environment and the potential opportunities that result from these changes (Baron, 2006). Ardichvili et al. (2003) argue that prior knowledge is an antecedent to entrepreneurial alertness, and cognitive frameworks (Baron and Ensley, 2006) or schema (Mitchell et al., 2004) acquired through experience facilitate pattern recognition. Haynie et al. (2009) report that individuals with no prior business experience detect fewer opportunities, although Smith et al. (2009) found that prior experience may be more important in the identification of tacit opportunities. Their study also reveals that entrepreneurs are more likely to undertake a systematic search for information for codified opportunities. Cognition is argued to play an important role in this activity (Keh et al., 2002). While entrepreneurs can be either active or passive in their search for opportunities (Ardichvili et al., 2003), access to information is important (Baron and Ensley, 2006).

Information from publications (Ucbasaran et al., 2008) and formal and social networks (Baron and Ensley, 2006; Ozgen and Baron, 2007) is positively associated with opportunity identification. Social networking is considered an important catalyst (Quan, 2012) or conduit (Batjargal, et al., 2013; Kontinen and Ojala, 2011) for information about new opportunities, and dense relationships can enhance identification performance (Pinho and de Sa, 2013). Batjargal et al. (2013) advise that social networks are particularly important when formal institutions are non-existent or inefficient. However, empirical findings are mixed on whether 
informal industry ties (Ozgen and Baron, 2007) or formal industry ties (Kontinen and Ojala, 2011) are more important.

Nonetheless, the importance of social networks is widely acknowledged in entrepreneurial studies, and in the East, guanxi is a recognised prerequisite to business relationships (Arias, 1998). Guanxi commonly refers to personal relationship networks of informal social bonds that individuals carry with expectations and obligations to facilitate the exchange of information and favours among themselves (DeKeijzer, 1992; Davies, et al., 1995; Lovett et al., 1999). Previous research identifies that social networks and guanxi may influence entrepreneurial opportunity identification in Chinese society (Yang et al., 2014), yet little is known about franchisee opportunity identification in a guanxi-dominated society. It is an important part of Chinese business culture (Yang, 2011), and its benefits include the provision of information and resources to smooth transactions and overcome bureaucracy (Davies et al., 1995). Research suggests that guanxi is considered a social means to overcome political, economic, and legislative obstacles to enterprise (Lee and Anderson, 2007; Gu et al., 2013). For international companies, guanxi is deemed to be an important consideration when expanding business in China, mainly at the initial stage of introduction, negotiation, and operation setup (Fan, 2002). Local Chinese entrepreneurs also look for some common guanxi links (Lee et al., 2001) that can be expanded or accumulated via clanships, friendships, or schoolmates, to gain business advantages (Tsang, 1998). Individuals within a guanxi social network tend to commit to each other on a long-term basis through a hidden norm of reciprocity that concerns equity and the exchange of favours (Ang and Leong, 2000). Previous studies suggest guanxi is positively influenced by decision-making uncertainty and negatively affected by opportunism (Lee et al., 2001; Davies et al., 1995). Lee and Anderson (2007) argue, however, that the informality of 
guanxi relationships compared to the formality of legal contractual agreements has led Chinese entrepreneurs to reduce its use in recent years.

\section{Opportunity evaluation}

Although deemed fundamental for entrepreneurial success, opportunity evaluation has received relatively limited research attention (Haynie et al., 2009). It is generally agreed that evaluation is a cognitive phenomenon (Mitchell et al., 2004; Haynie et al., 2009); however, emotions (Foo, 2009; Welpe et al., 2012), values and goals (Bishop and Nixon, 2006), and affective traits (Delgado-Garcia et al., 2012) also influence opportunity evaluation.

Research reveals different criteria used by entrepreneurs to evaluate opportunities. Baker et al. (2005) distinguish between objective (market size, rate of growth, level of competition) and demand (resources, tasks, and behaviours required for exploitation) criteria, stating that differences in opportunities influence the evaluation process. In contrast, Bryant (2006) identifies criteria that included strategic fit, knowing the market, trusting the other party, trusting one's gut, and assessing worst-case scenarios. While Lindsay and Craig (2002) also identify 'gut feelings', Bryant (2006) advises these are self-regulated to confirm or disconfirm evaluation decisions. Keh et al. (2002) contend that as evaluation is usually made under conditions of uncertainty, perceptions of risk are also important. More recently, Haynie et al. (2009) examined value, rarity, imitability, and limits on competition, identifying that opportunities relating to existing knowledge and skills were rated as more attractive, although entrepreneurs were attracted to those outside their skill set if rarity was high and competition limited. 
This brief review identifies a number of factors that influence opportunity identification and evaluation. Entrepreneurs' personal traits, prior knowledge, information search, and social networks are deemed relevant to opportunity identification, whereas their personal traits, prior knowledge, goals, and evaluation criteria, along with the nature of the opportunity influence its evaluation. As previous franchise studies have focussed on the personal traits of franchisees (Smith, et al., 2009), and this research is concerned with only franchise opportunities (e.g. opportunities of the same nature), this study focusses on prior knowledge, information search and the role of social networks, entrepreneurial goals, and evaluation criteria to address the following questions:

1) How do prior knowledge, information search, and social networks influence franchisee opportunity identification?

2) How do franchisee goals, evaluation criteria, and information search influence franchisee opportunity evaluation?

\section{Research design}

A qualitative approach was adopted in order to fully explore the activities undertaken by franchisees and the factors that influenced their actions. Qualitative studies allow researchers to get close to franchisees (Shaw, 1999) and explore the situational complexities of entrepreneurship (Bryant, 2006). Such studies also are suitable for inducing credible causal explanations to extend existing managerial practice (Maxwell, 2005).

As previously identified, Macau, a Special Administrative Region (SAR) of China with a Portuguese heritage, was deemed a suitable research context, given the recent growth of franchising in the SAR. This growth has been stimulated by favourable economic conditions and by government efforts to speed business development through the organisation of franchise 
expositions (MGTO, 2013). Macau also provides a different cultural context to examine franchising, considered important to franchise research (Weaven and Frazer, 2006)

A sample of 23 international and domestic food and beverage, retail, and professional service franchisees was identified using a snowball sampling process (Doherty, 2009). Representing approximately $30 \%$ of all franchise brands in Macau, the sample comprised franchisees who operated under single-unit and master franchise agreements. Master franchises enable franchisees to sub-franchise branded units over defined geographical territories (Brookes and Roper, 2011). Contractual agreements ranged between two and twenty years, and franchisees were operational from just under six months to over twenty years. While there are limitations of recall and survivor bias with the sample (Caessar, 2007), previous franchise studies demonstrate its potential value (Peterson and Dant, 1990; Seawright et al., 2011). The majority of the sample had no industrial experience in their chosen sector prior to business start-up, although some had previously been self-employed. Table 1 depicts the profile of the research sample.

\section{Table 1 here}

Data was collected through semi-structured interviews in Macau, lasting between one-half and one hour each with the franchisees who actually undertook the identification and evaluation process before signing franchise contracts. The interview schedule (see Appendix 1) was designed to gather data on informant backgrounds, the activities and processes undertaken to identify opportunities, the criteria used and activities undertaken to evaluate them, and the

reasons for their actions and decisions. The interview schedule was developed in English, translated into Cantonese, and back translated to achieve translational equivalence (Moore et $a l .$, 2004). The reverse process was undertaken for the interview transcripts. 
Data was analysed with NVivo 9.2 software. In the first instance, each transcript was saved as a node, and a classification was created to record each informant's background details using the attribute and value functions so that queries could be run against franchisee backgrounds. Another node was created for each transcript for the purpose of thematic coding. Analysis began with descriptive coding, where each transcript was coded according to whether informants were discussing opportunity identification or evaluation. This initial process resulted in the creation of 182 references to opportunity identification and 278 references to opportunity evaluation. Memos were created for each thematic code containing a list of all questions to be asked of the data. Table 2 provides an example of these memos for data coded under opportunity identification.

\section{Table 2 here}

These questions were then used to run queries and to create additional thematic nodes, which were documented in a coding journal. The process of creating memos of the particular questions to be asked of the data under each new thematic node was repeated until the data was exhausted. The final stage of the research entailed comparing the findings to the extant literature in order to draw conclusions to the study.

\section{Findings}

The findings reveal both similarities and differences in the identification and evaluation practices of master and single franchisees. These are presented in the following section according to the two research questions posed.

The influence of prior knowledge, information search, and social networks on opportunity identification 


\section{Prior Knowledge}

The findings reveal that prior knowledge had limited impact on opportunity identification in this study, as only six franchisees (three single, one multi and two master franchisees) had prior experience in their industrial sector. However, most franchisees reported identifying opportunities as a result of their perceptions of the market and the changing business environment. Master franchisees in particular, reported their perceptions of Macau 'opening up (F5)' and becoming a 'tourism city (F7)'. Accordingly, these franchisees considered there would be a demand for 'international brands (F18)' or 'known brands to impress the tourists (F7)'. As these resources were 'quite limited' in Macau, they reported looking for a product 'which is suitable to be introduced to Macau' (F10). One master franchisee summarised the situation:

'Macao is a tourism city, so our targets are mainly tourists. For a tourism city, a known brand will first impress the tourists. For example, when yougo for a trip, and you saw McDonald and "DoMcnald", which will you choose? For sure McDonald, right? Because they have this brand in mind already.' (F7)

In contrast, many single-unit franchisees reported identifying specific products or brands on their travels to Hong Kong or Taiwan which they believed could be introduced successfully to Macau. One franchisee described finding 'stores with many people waiting outside and thought, I couldn't help making profits in Macau (F1)'. Others explained they 'noticed that this brand was developing in Hong Kong (F21)', or that 'this service has been operated in Hong Kong or major cities in foreign countries, but there is none in Macau (F20)'. These franchisees therefore identified opportunities related to specific brands, rather than in the broader environment like master franchisees. 


\section{Information Search and Social Networks}

Only two single franchisees reported undertaking any information search at the opportunity identification stage, although they did not base their start-up decisions on the information. On probing, both master and single-unit franchisees revealed that they came upon franchisors or their brands through their social networks and 'by chance (F12)' or 'coincidence (F2, F7)', through 'fate (F17)' or 'a chance meeting (F20). Master franchisees reported their friends 'suggested to me to open one (F9)', or that they 'started to investigate with the recommendation of a friend as friends' referrals are very common in Macau (F18)', Single franchisees explained that they had a 'personal relationship (F16)' with the franchisor, or that 'my friend introduced me (F21)', or 'my friend introduced Mr. Choi. We dined and chatted and I learnt about this industry (F20)'. As one single franchisee explained:

I by chance learnt that one friend was granted this franchise in Macau.

We discussed this. I have this entrepreneurial idea after this (F13)'.

Social networks therefore appear to be more important than the information search in opportunity identification for both single and master franchisees.

The influence of franchisees' goals, evaluation criteria, and information search on opportunity evaluation

Franchisees reported two main goals for joining franchise chains, and the data reveals that these goals influenced the specific evaluation criteria used. It also identifies the impact of these goals on the information search activities undertaken during the evaluation process.

Franchisee Goals and Evaluation Criteria

Goal One: first to market 
Both master and single franchisees reported that a key goal was to be 'first to market (F5, F11)' to better exploit the opportunity identified. As a result, they identified the importance of finding 'a new brand (F20)' or products 'unique (F16)' to Macau, advising that 'the first thing is to choose a brand which does not exist in Macau (F6)'. Single franchisees who spotted brands on their travels also reported they wanted to ensure that they did not choose a brand with keen competition (F11)' or one 'in decline (F1)'. As one franchisee stated, 'the main reason for us to sign this agreement is that there is not yet any [brand $\mathrm{x}$ ] in Macau, so we will be the first (F6).' The level of competition was thus an important evaluation criteria for both master and single franchisees.

Single-unit franchisees further advised that 'joining a franchise is a fast and direct method (F20)' or 'the fastest way (F16)' to market because it enabled them to quickly 'gain experience' and to start their 'business as soon as possible (F11)' rather than having 'to start from the very beginning for brand development (F15)'. As one franchisee summarised, 'choosing to join a franchise is somehow a shortcut and it saves time from studying the business (F6)' For these single franchisees, the franchise business format was used to assess the relative speed of their business start-up and whether they could realise goals of being first to market, deemed 'commercially important (F11)'.

\section{Goal Two: long-term growth}

A second key goal reported by both master and single franchisees was that of long-term growth beyond the initial contractual agreement. Master franchisees in particular sought expansion into mainland China. These franchisees wanted to expand to "nearby regions like Zhognshan, Jiangmen (F12)', and 'to sell in the Pearl River Delta (F7)', explaining that 'Macau is somewhat like a showroom of China'. As such they used 'Macau as a platform (F7)' or as a 
'testing point to pave the way for the China market (F4)'. One master franchisee expressed his ambitious goals accordingly:

'I've got a plan in mind and I have discussed it with headquarters. I want to expand the company by engaging in upstream industries. That is, we can take over some factories to produce our own products for supply to our shops in Hong Kong, Macau and the Mainland. I really want to make this brand part of me (F5)'.

While single-unit franchisees also reported their desire for growth, their plans were not as ambitious as those of master franchisees. Single franchisees advised of 'a goal to become the regional agent (F11)', a 'target to buy the dealership in Macau (F16)'. Nonetheless, both single and master franchisees placed importance on future expansion, which in turn, influenced the evaluation criteria used.

\section{Evaluation Criteria:}

In line with their goals for long-term growth, both single and master franchisees reported seeking information on the franchisor's mission, network growth history, current locations, and future growth plans, using these as a set of evaluation criteria in order to make judgements about the long-term vision of the brand. As one master franchisee explained:

'The most important thing is the future plan. Even if you charge me a "very low fee", I won't choose you if you don't have a long-term plan. That means how many stores they will open; in which places and countries will they continue to develop (F18).'

Although these criteria were important to both master and single franchisees, what was potentially more importance was the 'confidence (F3, F7, F11, F12, F16, F19, F20)' they had 
in the franchisor. For master franchisees, the franchisor's 'social status (F2)' and 'reputation (F2, F12)' helped to create this confidence. As one explained:

'In considering the prospect of this business, because their brand has many successful cases in Shanghai, I am confident in this business because it has succeeded in other areas (F7)'.

For both master and single franchisees, the data reveals that franchisors' attitudes and the relationships built prior to contract signature were also important in developing not only confidence, but 'trust (F5, F6, F9, F10, F11, F12, F13, F14, F15, F16, F17, F18, F20, F22, F23)'. One master franchisee advised, 'We have to see their attitude. This is very important. You build trust through their sincere attitude (F19)'. Single franchisees emphasised the importance of relationships, and more specifically 'a relationship in harmony (F21)', 'a good relationship (F16, F22)', or 'faith in the relationship; (F12, F13)' and the franchisor to deliver the support promised. Franchisees' goals and evaluation criteria also appear to have influenced the information search activities undertaken during evaluation, as presented in the following section.

\section{Information Search}

Master and single franchisees reported gathering information on their chosen criteria via the internet in the first instance, but did not rely solely on this data. They also visited franchisor headquarters, factories, and other franchise units to seek confirmation of the facts reported online and in person. As one franchisee advised, 'you have to analyse the information rationally otherwise you will be easily deceived (F11)'. 
Master franchisees revealed a clear scepticism about franchising, advising: 'some franchisees don't have conscience. They just got some ideas in mind but don't even have any backup (F12)' so 'you have to understand whether the company is real (F19)'. Single franchisees concurred, suggesting 'many of them [franchisees] only have a counter with posters, etc., but without any actual shops. What they have is only an idea or formula (F11)'. Accordingly, you have to 'make sure the company really exists (F11)'.

The validation of the franchisor and its offer were therefore achieved through independent research. Master franchisees in the study reported undertaking more research from a wider range of sources, particularly those with self-employment experience. They collected data on local economics, brand popularity, locations, competitors, rent, and remuneration, and compared it to other franchisee locations, explaining, 'We have done the feasibility study. Just like our enterprise, when opening a company, we have to do the feasibility study (F9)'. In contrast, single-unit franchisees reported undertaking 'non-specific studies (F17)' or even 'an unprofessional analysis (F20)' to roughly gage franchisor claims and financial viability. Additional visits to existing franchisees were sometimes undertaken for further validation. One franchisee reported, 'we have been to the [brand units] at Causeway Bay and Mong Kok; we chatted with the owners, asking them their business there. They claimed that they could break even (F1)'.

In addition, master franchisees reported the 'risks' (F9) they were undertaking in relation to franchisor support post contract signature. Accordingly, they wanted 'the type of support listed out very precisely in the franchise agreement (F10)' or the offered support 'listed out clearly (F18)' and in 'black and white (F7)'. Franchisees counselled, 'you have to make sure that the franchisor won't just sell the franchise to you and charge you the royalty without doing 
anything for you (F15)', 'because some franchisors would disappear or care about nothing after assisting with the establishment (F19)'. Franchisees of international networks in particular were concerned with initial and continued training, supply chain distribution, marketing and promotional support, and fluctuating exchange rate mechanisms, considering these to be risks that could impact the financial viability of their start-up. Confirmation visits were therefore used to evaluate the extent to which the franchisor's initial and ongoing support would actually materialise after signing the contract. One franchisee advised, 'you need to use different means to assure reliable impressions (F9)' and that the franchisor is 'not deceiving us (F19)'.

Although one single franchise did suggest that they explored 'written contracts in detail' and 'we can directly quote article 5 in chapter 3 (F21)', most were more concerned with the risks associated with the verbal promises made the franchisor representatives in relation to their goals for growth. These franchisees questioned whether franchisors would 'live up to their word (F11)' or 'whether their promises will be fulfilled (F16)' in relation to territorial rights and future expansion plans. They stated that verbal promises were 'the most important problem (F16)', as 'they didn't guarantee anything but that you have to take the risk as a unit franchisee (F9)'. Master franchisees were not immune to this risk. As one explained, 'I have to open three this year, if I can open the fourth store, can the new store fee be waived? They would not put that down in black and white, but they claimed that they would fight for it when it really happened (F15)'.

Given these perceived risks, both master and single franchisees reported that the 'communication (F16, F18, F20, F22)' with the franchisor throughout the evaluation process was important to assess franchisors' attitude. One master franchisee explained, 'To be successful, I must have a certain level of connection with the headquarters in Taiwan. That is 
why we did not put the brand name as the priority, but communication (F19)'. Single and multiunit franchisees concurred, reporting the need for 'room for discussion (F20)' to assess the 'franchisor's reliability (F6)'. For all franchisees therefore, the degree to which they could 'trust (F5)' franchisors them to help realise their goals was important in the evaluation process. As one single franchisee summarised, 'Trust is very important; if not, it is better to establish operations alone (F23)'.

\section{Discussion}

\section{Prior knowledge, information search, social networks, and opportunity identification}

The findings of the study revealed that opportunities are identified through exploitation of local market knowledge and knowledge gained through travelling internationally. Franchisees therefore identified what entrepreneur researchers label as value-sought opportunities, from a consumer-demand perspective (Lindsay and Craig, 2002). However, unlike the arguments put forward in the literature stating that prior knowledge and industry-relevant experience (Shane, 2000) are the antecedents of opportunity alertness (Ardichvili et al., 2003), in this study, only six franchisees had previous experience in the franchisor's industry sector. Thus, prior industry knowledge appears to be less relevant in the identification of codified franchise opportunities, a finding which contradicts arguments by Smith et al. (2009).

Added to this finding is the lack of sufficient information search during opportunity identification. Though recognised as important to opportunity identification (Baron and Ensley, 2006), only two franchisees in the sample reported undertaking any research. However, this research wasn't used to identify alternative opportunities or inform decisions. Instead, both master and single-unit franchisees from different sectors relied heavily on social networks to act as information conduits, as Kontinen and Ojala (2011) and Quan (2012) purport. These 
networks served as a substitute for prior industrial knowledge and helped franchisees to connect the dots between changes in the environment and potential opportunities (Baron, 2006). The use of social networks also appears to have influenced franchisees to take decisions about industry sectors, franchising, and brands simultaneously. Altinay et al. (2013) also found that franchisees made these decisions simultaneously when introduced to franchisors by friends and family, albeit with potentially negative consequences. The researchers identified that these franchisees failed to undertake an information search process, as did the franchisees in this study during opportunity identification.

The findings of this study provide further insight into franchising literature by revealing the importance of social networks in franchisee business start-ups. It became apparent that social networks can influence and shape the opportunity identification stage of franchising. What is even more striking is that social networks are culture bound and embedded within the social structure in which opportunity identification takes place. This study is one of the few studies demonstrating the significance of guanxi social networks in opportunity identification. As widely acknowledged by the franchisees in the study, guanxi-enabled information sharing and exchange was crucial for opportunity identification. This finding is also in line with those of DeKeijzer (1992), Davies et al. (1995), and Lovett et al. (1999). On the other hand, while Batjargal et al. (2013) found that social networks support opportunity identification in the absence of formal institutions, this study suggests that they can also complement formal institutions, as there is a formal franchise association in Macau.

This study also makes a distinct contribution to the existing literature through explaining the possible reasons why there is heavy reliance on social networks in franchisee opportunity identification, an important aspect neglected by the previous franchising research. It could be 
that the lack of prior industry knowledge may have influenced franchisees to adopt a passive role (Ardichvili et al., 2003) and rely on social networks. Alternatively, the information obtained through guanxi networks from trusted sources could be perceived to be more reliable than one's own research, given Macau and China's cultural, political, economic, and legal context (Gu et al., 2013). Thus, guanxi as 'an accessing strategy' (Chang, 2011:318) continues to be prevalent in China, where many resources remain restricted, and individuals seek business opportunities which may not be available to the public (Xia and Pearce, 1996). This finding contradicts Smith et al.'s (2009) argument that entrepreneurs are more likely to undertake a systematic information search for codified opportunities. However, franchisees did report conducting a more thorough information search to evaluate opportunities, as discussed in the following section.

\section{Franchisee goals, evaluation criteria, information search, and opportunity evaluation}

The findings of the study revealed that franchisee goals and evaluation criteria play an instrumental role in opportunity evaluation. Regardless of industry sector or type of franchise agreement, franchisees in this study identified clear goals of being 'first to market' to reap the advantages of this competitive position and to realise their goals for long-term growth. This finding is in line with the previous research, which found that prospective franchisees recognise that their success is dependent on network expansion (Bennet et al., 2010). In particular, franchising is considered a suitable means-end relationship (Shane 2000), providing firstmover advantages, particularly when franchisees lack industry knowledge.

This study however goes further than the existing literature by identifying how franchisees' goals influence the criteria used to evaluate opportunities. More specifically, it highlights the importance of goal congruity when franchisees are deciding to join a network, as argued by 
Frazer et al. (2007), and offers an explanation as to why goals are important in the entrepreneurial evaluation process (Bishop and Nixon, 2006). It also provides support for Guillox et al.'s (2004) argument that franchisors should share strategic network perspectives with franchisees who have their own strategic vision to assess goal alignment. As franchisees in this study also sought information on initial franchise fees, royalty rates, and potential budgets required to assess the feasibility of their business start-up, the study reveals their use of a mix of objective and demand criteria previously identified by entrepreneurial researchers (Baker et al., 2005) in relation to their long-term goals for growth. This study contributes to the franchising literature by demonstrating how these criteria influence and act upon each other, thus influence opportunity evaluation.

More importantly, the findings of this study also suggest that both franchisees' goals and evaluation criteria influence the type of information and the activities undertaken in the evaluation process. In particular, franchisees' goal to be part of a franchise chain that is reliable and trustworthy determine both the type of information needed and franchisees' informationgathering activities. Reliability and trustworthiness of franchisors are perceived as 'risk factors' by franchisees that could determine the future success of the partnership. These findings therefore provide empirical support for Keh et al.'s (2002) argument that perceptions of risk are important when evaluating opportunities. However, what is crucial and also became apparent in this study is how franchisees engage in information search activities in order to minimise these risks. Although previous franchising literature identified risk and risk evaluation as an important dimension of franchising, this study makes progressive contribution by explaining how risks are managed by the franchisees through engaging in information search activities. 
The findings reveal that master and single-unit franchisees may undertake different degrees of due diligence when evaluating opportunities. However, they also reveal that both franchisees did not rely on 'gut feelings' as entrepreneurial researchers have identified (Bryant, 2006; Lyndsay and Craig, 2002). Rather they sought external evidence to fully evaluate both objective and demand criteria, confirm initial perceptions of franchisors' reliability and trustworthiness, and minimise business start-up risk. In addition, franchisees' perceptions of reliability and trust were also informed by their interaction and communication with franchisors. During these interactions, franchisees thus also used relational criteria to evaluate the franchise opportunity. Bryant (2006) previously identified trust and strategic fit as entrepreneurial opportunity evaluation criteria. This study makes a distinct contribution to the literature by validating the interface between trust and strategic fit and their influence in franchising. Trust as a relational criteria, is important when franchisees lack prior industry knowledge. Strategic fit is particularly important in evaluating the realisation of franchisees' goals, first-mover advantages and long-term growth, and their congruence with those of the franchisor. The informality of guanxi relationships may have reduced its use amongst Chinese entrepreneurs in recent years (Lee and Anderson, 2007), the findings of this study show its influence on business opportunity evaluation is still evident. In particular, information obtained from trusted guanxi sources facilitates franchisees' opportunity evaluation, especially where franchisees lack prior knowledge, and novel information might not be equally or easily accessible by all.

\section{Conclusions}

\section{Theoretical Contributions}

This study sought to identify and analyse the factors that influence franchisees' identification and evaluation of opportunities as an entrepreneurial process. In doing so, it makes two 
contributions to franchise literature through being informed by franchise/entrepreneurship interface literature. First, it provides an alternative and complementary perspective to our current understanding of franchise chain growth by shedding further insight into franchisee decision-making prior to contract signature, the actions undertaken to identify franchise opportunities. It became apparent that prior knowledge, information search and social networks influence franchisee opportunity identification. In particular, this study makes a unique contribution to the literature by demonstrating how social networks play a key role in valuesought opportunity identification when franchisees lack prior industry knowledge. The influence of social networks and guanxi on opportunity identification is important in both domestic and international franchise networks.

Second, this study showed how franchisee goals, evaluation criteria, and information search influence and act upon each other and thus influence franchisee opportunity evaluation. In particular considering the interrelated nature of these factors within the context of a franchise appears to be crucial for opportunity evaluation. The study also identifies the relevance of franchisees' long-term goals for growth and the use of objective, demand, and relational evaluation criteria in relation to these goals, and the importance of goal congruity to franchisees. Relational criteria appear to be particularly important to mitigate franchisees' business start-up risks and realise their long-term goals. The activities undertaken to gather information during the evaluation process to validate franchisor-provided data and communication and interaction with franchisors are both essential to assess relational criteria and to the risk-mitigation process, even if originally introduced to the opportunity through social or guanxi networks. 


\section{Managerial Implications}

The study yields implications for franchise stakeholders. Franchisors should endeavour to understand the extent to which franchisees seek first-mover advantages in their selection process and the degree to which their information and organisational processes support or hinder the realisation of these goals. For franchisors seeking rapid development in new markets, assessing prospective franchisees' first-mover and long-term development goals could assist market penetration and chain growth, particularly in locations with a shortage of franchisee applicants. Franchisors should consider using their goals for expansion as signals to distinguish themselves from the competition and attract prospective franchisees. Recruitment of franchisees that have clear expansion plans may also provide franchisors with greater control if these franchisees emulate franchisors as they develop their own mini chains. In addition, with the role of social networks and guanxi identified, franchisors and franchise associations should seek to explore how to make better use of these networks to recruit potential franchisees, particularly for industrial sectors seeking to penetrate new markets. Both franchisors and franchisees should embrace the role guanxi plays in gaining and evaluating business opportunities in China, which were previously dominated by state-owned enterprises and where entrepreneurial opportunities for franchisees were limited. At the same time, the challenge of utilising an informal guanxi relationship and its impact on developing a formal contractual business relationship should not be underestimated as economic and social reforms continue in the country. Finally, franchisors should examine negotiation styles and communication practices to ensure they positively influence franchisees' perceptions of reliability and trustworthiness. The current practice of representatives making verbal promises to franchisees and the impact these have on franchisees' perceptions of risk should be considered. 
Prospective franchisees are advised to use different sources of information to thoroughly assess franchise opportunities using goal-informed objective, demand, and relational criteria, regardless of whether they were introduced to opportunities through social networks. Franchisees should ensure that sufficient time is spent in communication with franchisors to adequately assess relational criteria and minimise risks and ensure the congruity of their goals with those of the franchisor prior to contract signature.

\section{Further Research}

While this qualitative study facilitated a deeper understanding of the activities franchisees undertake and the factors that influence their actions, the small sample size limits the generalisability of the findings. A larger quantitative inquiry is recommended to test the relationships identified in this study across a range of different industrial sectors, particularly research that tests the relationship between social networks and/or guanxi in franchisee opportunity identification and chain growth. Further research that includes prospective franchisees that identified, evaluated, and then discounted franchise opportunities would also be beneficial, as would research in the context of different countries. 


\section{References}

Altinay, L., Brookes, M. and Aktas, G. (2013), "Selecting Franchise Partners: Franchisee Perspectives, Processes and Criteria", Tourism Management, Vol. 37, No. , pp. 176185.

Ang, S. and Leong, S. (2000), "Out of the mouths of babes: business ethics and youth in Asia”, Journal of Business Ethics, Vol. 28, pp. 129-144.

Ardichvili, A., Cardozo, R. and Ray, S. (2003), "A theory of entrepreneurial opportunity identification and development", Journal of Business Venturing, Vol. 18, No. 1, pp. 105123.

Arias, J. (1998), 'A relationship marketing approach to guanxi”, European Journal of Marketing, Vol.32, No. 1/2, pp. 145-156.

Baker, T., Gadajlovic, E. and Lubatkin, M. (2005), "A Framework for Comparing Entrepreneurship Processes across Nations", Journal of International Business Studies, Vol. 36, No. 5, pp. $492-504$.

Baron, R. (2006), "Opportunity recognition as pattern recognition: How entrepreneurs "connect the dots" to identify new business opportunities", Academy of Management Perspectives, Vol. 20, No.1, pp. 104-119.

Baron, R. and Ensley, M. (2006), "Opportunity recognition as the detection of meaningful patterns: Evidence from comparisons of novice and experienced entrepreneurs", Management Science, Vol. 52, No. 9, pp. 1331-1344.

Barthelemy, J. (2008), "Opportunism, Knowledge and the Performance of Franchise Chains", Strategic Management Journal, Vol. 29, No. 13, pp.1451-1463.

Batjargal, B., Hitt, A., Tsui, A., Arregle, J., Webb. W. and Miller, T. (2013), "Institutional Polycentrism, Entrepreneurs' Social Networks, and New Venture Growth", Academy of Management Journal, Vol. 56 No. 4, pp. 1024-1049.

Bennet, S., Frazer, L. and Weaven, S. (2010), "What Prospective Franchisees Are Seeking", Journal of Marketing Channels, Vol. 17, No. 1, pp. 69-87.

Bishop, K. and Nixon, R. (2006), "Venture Opportunity Evaluations: Comparisons between Venture Capitalists and Inexperienced Pre-Nascent Entrepreneurs", Journal of Developmental Entrepreneurship, Vol. 11 No. 1, pp. 19-33.

Brookes, M. and Altinay, L. (2011), "Franchise Partner Selection: Perspectives of Franchisors and Franchisees", Journal of Services Marketing, Vol. 25, No. 5, pp. 336348.

Brookes, M. and Roper, A. (2011), "International Master Franchise Agreements: An Investigation of Control from Operational, Relational and Evolutionary Perspectives", European Journal of Marketing, Vol. 45, No. 7/8, pp. 1253-1276. 
Bryant, P. (2006), "Self-regulation and decision heuristics in entrepreneurial opportunity evaluation and exploitation", Management Decision, 45(4): 732-748.

Cessar, G. (2007), "Money, money, money? A longitudinal investigation of entrepreneurial career reasons, growth preferences and achieved growth", Entrepreneurship \& Regional Development, Vol. 19, No. 1, 89-107.

Chang, K. (2011), “A path to understanding guanxi in China's transitional economy: variations on network behaviour", Sociological Theory, Vol. 29, No. 4, pp. 315-339.

Chen, H. (2010), "The explanations of agency theory on international multi-unit franchising in the Taiwanese marketplace", The International Journal of Organizational Innovation, Vol. 3 No. 1, pp. 53-71.

Chirico, F., Ireland, R. and Sirmon, D. (2011), "Franchising and the Family Firm: Creating Unique Sources of Advantage Through "Familiness", Entrepreneurship Theory and Practice, Vol. 35, No. 3, pp. 483-501.

Clarkin, J. and Rosa, P. (2005), "Entrepreneurial Teams within Franchise Firms", .International Small Business Journal, Vol. 23, No. 3, pp. 303-334.

Combs, J. and Ketchen, D. (2003), "Why Do Firms Use Franchising as an Entrepreneurial Strategy? A Meta-Analysis", Journal of Management, Vol. 29, No. 3, pp. 443-465.

Combs, J., Ketchen, D. and Short, J. (2011), Franchising Research: Major Milestones, New Directions, and Its Future Within Entrepreneurship", Entrepreneurship Theory and Practice, Vol. 35, No. 3, pp. 413-425.

Corbett, A. (2005), "Experiential Learning Within the Process of Opportunity Identification and Exploitation”, Entrepreneurship Theory and Practice, Vol. 29, No. 4, pp. 473-491.

Croonen, E. and Brand, M. (2013), "Antecedents of franchisee responses to franchisorinitiated strategic change", International Small Business Journal, Vol. 33, DOI: 10.11.1177/0266242613499805.

Dada, O. and Watson, A. (2013), "Entrepreneurial Orientation and the Franchise System: Organisational Antecedents and Performance Outcomes", European Journal of Marketing, Vol. 47, No. 5/6, pp. $790-812$.

Davies, M., Lassar, W., Manolis, C., Prince, M. and Winsor, R. (2011), “A model of trust and compliance in franchise relationships", Journal of Business Venturing, Vol. 26, No. 3, pp. 321-340.

Davies, H., Leung, T., Luk, S. and Wong, Y. (1995), “The benefits of Guanxi”, Industrial Marketing Management, Vol, 24, pp.207-214.

De Keijzer, A. (1992), “China: business strategies for the 90s”, Pacific View Press, Berkeley, CA. 
Delgado-Garcia, J., Rodriguez-Escudero, A. and Martin-Cruz, N. (2012), "Influence of Affective Traits on Entrepreneurs' Goals and Satisfaction", Journal of Small Business Management, Vol. 50, No. 3, pp. 408-428.

Doherty, A. (2009), "Market and partner selection processes in international retail Franchising", Journal of Business Research, Vol. 62, No. 5, pp. 528-534.

Dutta, D. and Crossan, M. (2005), "The Nature of Entrepreneurial Opportunities: Understanding the Process Using the 4I Organizational Learning Framework", Entrepreneurship Theory and Practice, Vol. 29, No. 4, pp. 425-449.

Fan, Y. (2002), 'Questioning guanxi: definition, classification and implications”, International Business Review, Vol.11, pp. 543-561.

Foo, M. (2009), “Emotions and Entrepreneurial Opportunity Evaluation”, Entrepreneurship Theory and Practice, Vol. 33, No. 2, pp. 375-393.

Frazer, L., Merrilees, B. and Wright, O. (2007), "Power and control in the franchise network: an investigation of ex-franchisees and brand piracy", Journal of Marketing Management, Vol. 23, No. 9, pp.1037-1054.

Gaglio, C. and Katz, J. (2001), "The Psychological Basis of Opportunity Identification: Entrepreneurial Alterness", Small Business Economics, Vol. 16, No. 2, pp. 95-111.

Gartner, W., Carter, N. and Reynolds, P. (2010), "Entrepreneurial behavior: Firm organizing processes", in Z. Acs \& D. Audretsch (Eds.), International handbook series on entrepreneurship, Springer, New York. Springer, pp. 99-127.

Gillis. W., McEwen, E., Crook, T. and Michael, S. (2011), "Using Tournaments to Reduce Agency Problems: The Case of Franchising", Entrepreneurship Theory and Practice, Vol. 35, No. 3, pp. 427-447.

Grace, D. and Weaven, S. (2011), “An empiricial analysis of franchisee value-in-use, investment risk and relational satisfaction", Journal of Retailing, Vol. 87, No. 3, pp. 366380 .

Grace, D., Weaven, S., Frazer, L. and Giddings, J. (2013), "Examining the role of franchisee normative expectations in relationship valuation", Journal of Retailing, Vol. 89, No. 2, pp. 219-230.

Grewel, D., Iyer, R., Javalgi, R. and Radulovich, L. (2011), "Franchise Partnership and International Expansion: A Conceptual Framework and Research Propositions", Entrepreneurship Theory and Practice, Vol. 35, No. 3, pp. 533-557.

Grunhagen, M. and Dorsch, M. (2003), "Does the franchisor provide value to franchisees? Past, current and future value assessments of two franchise types", Journal of Small Business Management, Vol. 41, No. 4, pp. 366-384. 
Grunhagen, M. and Mittelstaedt, R. (2005), "Entrepreneurs or Investors: Do Multi-unit Franchisees Have Different Philosophical Orientations?", Journal of Small Business Management, Vol. 43, No. 3, pp. 207-225.

Grunhagen, M., Dant, R. and Zhu, M. (2012), “Consumer Perspectives on American Franchise Offerings: Variety Seeking Behaviour in China." Journal of Small Business Management, Vol. 50, No. 4, pp. 596-620.

Gu, H., Ryan, C., Li, B. and Gao, W. (2013), "Political connections, guanxi and adoption of CSR policies in the Chinese hotel industry: is there a link?", Tourism Management, Vol. 34, pp. 231-235.

Guilloux, V., Gauzente, C., Kalika, M. and Dubost, N. (2004), "How France’s Potential Franchisees Reach Their Decisions: A Comparison with Franchisers' Perceptions", Journal of Small Business Management, Vol. 42, No. 2, pp. 218-224.

Hansen, D., Sharder, R. and Monllor, J. (2011), "Defragmenting Definitions of Entrepreneurial Opportunity”, Journal of Small Business Management, Vol. 49, No. 2, pp. 283-304.

Harmon, T. And Griffiths, M. (2008), "Franchisee perceived relationship value", Journal of Business and Industrial Marketing, Vol. 23, No. 4, pp. 256-263.

Haynie, M., Shepherd, D. and McMullen, J. (2009), "An Opportunity for Me? The Role of Resources in Opportunity Evaluation Decisions", Journal of Management Studies, Vol. 46, No. 3, pp. 337-361.

Hoy, F. (2008), "Organizational Learning at the Marketing/Entrepreneurship Interface", Journal of Small Business Management, Vol. 46, No. 1, pp. 152-158.

International Franchise Association (2011), International Franchising, www.franchise.org/ accessed on March 15, 2013

Kaufmann, P. and Stanworth, J. (1995), "The Decision to Purchase a Franchise: A Study of Prospective Franchisees", Journal of Small Business Management, Vol. 33, No. 4, pp. 22-32.

Kaufmann, P. and Dant, R. (1999), "Franchising and the Doman of Entrepreneurship Research”, Journal of Business Venturing, Vol. 14, No. 1, pp. 5-16.

Keh, H., Foo, M. and Lim, B. (2002), "Opportunity Evaluation under Risky Conditions: The Cognitive Processes of Entrepreneurs", Entrepreneurship Theory and Practice. Vol. 27, No. 2, pp. 125-148.

Knight, R. (1984), “The Independence of the Franchisee Entrepreneur”, Journal of Small Business Management, Vol. 22, No. 2, pp. 53-61.

Knight, R. (1986), "Franchising from the franchisors and franchisees points of view", Journal of Small Business Management, Vol. 24, No. 3, pp. 1-15. 
Kontinen, T. and Ojala, A. (2011), "International Opportunity Recognition among Small and Medium Sized Family Firms”, Journal of Small Business Management, Vol. 49, No. 3, pp. 490-514.

Lee, E. and Anderson, A. (2007), "The role of guanxi in Chinese entrepreneurship", Journal of Asia Entrepreneurship and Sustainability, Vol. 3, No. 3, pp. 38-51.

Lee, D., Pae, J. and Wong, Y. (2001), "A model of close business relationships in China (guanxi)", European Journal of Marketing, Vol. 35, No. 1/2, pp. 51-69.

Lindsay, N. and Craig, J. (2002), "A Framework for Understanding Opportunity Recognition", The Journal of Private Equity, Vol. 6, No. 1, pp. 13-24.

Lovett, S., Lee, C. and Raja, K. (1999), “Guanxi versus the market: ethics and efficiency”, Journal of International Business Studies, Vol. 30, No. 2, pp.231-248.

Lucia-Palacios, L., Bordonaba-Juste, V., Madanoglu, M. and Alon, I. (2014), "Franchising and value signalling", Journal of Services Marketing, Vol. 28, No. 2, pp. 105-115.

Martiz, A. and Nieman, G. (2006), "Entrepreneurial orientation in a franchise home entertainment system”, SAJEMS, Vol. 9, No.1, pp. 1-16.

Maxwell, J. (2005), Qualitative research design: An interactive approach. Applied social research methods series, Vol. 41, Sage Publications, Thousand Oaks, CA.

Meek, W., Davis, B., Sramek, M., Baucus, M. and Germain, R. (2011), "Commitment in Franchising: The Role of Collaborative Communication and a Franchisee's Propensity to Leave", Entrepreneurship Theory and Practice, Vol. 35 (3), No. pp. 559-581.

Merrilees, B. and Frazer, L. (2006), "Entrepreneurial franchisees have hidden superior marketing systems 2, Qualitative Market Research: An International Journal, Vol. 9, No. 1, pp. 73-85.

MGTO (2011), Statistic released by the Macau Government Tourist Office http://industry.macautourism.gov.mo/en/, accessed on September 14, 2013.

Michael, S. and Combs, J. (2008), "Entrepreneurial failure: The case of franchisees", Journal of Small Business Management, Vol. 46, No. 1, pp. 73-90.

Michael, S. (2003), "First mover advantage through franchising", Journal of Business Venturing, Vol. 18, No. 1 pp. 61-80.

Mitchell, R., Busenitz, L., Lant, T., McDougall, P., Morse, E. and Smith, J. (2004), "The Distinctive and Inclusive Domain of Entrepreneurial Cognition Research", Entrepreneurship Theory \& Practice, Vol. 28, No. 6, pp. 505-518.

Moore, C., Birtwistle, G. And Burt, S. (2004), "Channel power, conflict and conflict resolution in international fashion retailing", European Journal of Marketing, Vol. 38, No. 7, pp. 749-769. 
Moroz, P. and Hindle, K. (2012), "Entrepreneurship as a Process: Toward Harmonizing Multiple Perspectives", Entrepreneurship Theory \& Practice, Vol. DOI: 10.1111/j.1540-6520.2011.00452.x

Ozgen, E. and Baron, R. (2007), "Social sources of information in opportunity recognition: Effects of mentors, industry networks and professional forums", Journal of Business Venturing, Vol. 22, No. 2, pp. 174-192.

Paswan, A. and Witmann, C. (2009), "Knowledge management and franchise systems", Industrial Marketing Management, Vol. 38, No. 2, pp. 173-180.

Peterson, A. and Dant, R. (1990), "Perceived Advantages of the Franchise Option from the Franchisee Perspective: Empirical Insights from a Service Franchise", Journal of Small Business Management, Vol. 29, No. 3, pp. 46-61.

Pinho, C. and de Sa, S. (2013), "Entrepreneurial Performance and Stakeholders' Relationships: A Social Network Analysis Perspective", International Journal of Entrepreneurship, Vol. 17, No. 1, pp. 1-19.

Quan, X. (2012), "Prior Experience, social network and levels of entrepreneurial intentions", Management Research Review, Vol. 35, No. 10, pp. 945-957.

Sardy, M. and Alon, I. (2007), "Exploring the differences between franchisee entrepreneurs and nascent entrepreneurs", International Entrepreneurship Management Journal, Vol. 3, No. 4, pp. 403-418.

Seawright, K., Smith, I., Mitchell, R. and McClendon, R. (2011), "Exploring Entrepreneurial Cognition in Franchisees: A Knowledge-Structure Approach", Entrepreneurship Theory \& Practice, Vol. 37, No. 2, pp. 201-227.

Shane, S. (2000), "Prior Knowledge and the Discovery of Entrepreneurial Opportunities", Organization Science, Vol. 11, No. 4, pp. 448-469.

Shane, S. (2012), "Reflections on the 2010 AMR Decade Award: Delivering on the Promise of Entrepreneurship as a Field of Research", Academy of Management Review, Vol. 37, No. 1, pp. 10-20.

Shane, S. and Venkataraman, S. (2000), "The Promise of Entrepreneurship as a Field of Research”, Academy of Management Review, Vol. 25, No. 1, pp. 217-226.

Shaw, E. (1999), "A guide to the qualitative research process: evidence from a small firm study", Qualitative Market Research An International Journal, Vol. 2, No. 2, pp. 59-70.

Silkoset, R. (2013), "Negative and positive effects of social capital on co-located firms'withholding efforts", European Journal of Marketing, Vol. 47 No. 1/2, pp. 174197

Smith, B., Matthews, C. and Schenkel, M. (2009), "Differences in Entrepreneurial Opportunities: The Role of Tacitness and Codification in Opportunity Identification", Journal of Small Business Management, Vol. 47, No. 1, pp. 38-57. 
Stanworth, J. and Kaufmann, P. (1996), "Similarities and Differences in UK and US Franchise Research Data: Towards a Dynamic Model of Franchisee Motivation", International Small Business Journal, Vol. 14, No. 3, pp. 57-70.

Tsang, E. (1998), "Can guanxi be a source of sustained competitive advantage for doing business in China?", The Academy of Management Executive, Vol. 12, No. 2, pp. 64-73.

Ucbasaran, D., Wright, M. and Westhead, P. (2008), "Opportunity identification and pursuit: Does an entrepreneur's human capital matter?", Small Business Economics, Vol. 30, No. 2,pp. 153-170.

Venkataraman, S., Dew, N. and Forster, W. (2012), "Reflections on the 2010 AMR Decade Award: Wither the Promise? Moving Forward with Entrepreneurship as a Science of the Artificial”, Academy of Management Review, Vol. 37, No. 1, pp. 21-22.

Wales, W., Gupta, V. and Mousa, F. (2013), "Empirical research on entrepreneurial orientation: An assessment and suggestions", International Small Business Journal, Vol. 31, No. 4, pp. 357-383.

Weavin, S. and Frazer, L. (2006), "Investment incentives for single and multiple unit franchisees”, Qualitative Market Research: An International Journal, Vol. 9, No. 3, pp. 225-242.

Welpe, I., Sporrle, M., Grichnik, D., Michl, T. and Audretsch, D. (2012), "Emotions and Opportunities: The Interplay of Opportunity Evaluation, Fear, Joy, and Anger as Antecedent of Entrepreneurial Exploitation", Entrepreneurship Theory \& Practice, Vol. 36, No. 1, pp. 69-96.

Williams, D. (1999), "Why do entrepreneurs become franchisees? An empirical analysis of organizational choice”, Journal of Business Venturing, Vol. 14, No. 1, pp. 103-124.

Withane, S. (1991), "Franchising and Franchisee Behaviour: An Examination of Opinions, Personal Characteristics, and Motives of Canadian Franchisee Entrepreneurs", Journal of Small Business Management, Vol. 29, No. 1, pp. 22-29.

Xin, C. and Pearce, J. (1996), "Guanxi: connections as substitutes for formal institutional support”, Academy of Management Journal, Vol. 39, pp. 1641-1658.

Yang, F. (2011), "The importance of Guanxi to multinational companies in China", Asian Social Science, Vol. 7, No. 7, pp. 163-168.

Yang, J., Ryan, C. and Zhang, L. (2014), "External entrepreneurs/investors and guanxi: hostels in a tourism area, Xinjiang, China", International Journal of Contemporary Hospitality Management, Vol. 26, No. 6, pp.833-854. 
Table 1: Franchise Sample

\begin{tabular}{|c|c|c|c|c|c|c|c|c|}
\hline Code & $\begin{array}{c}\text { Franchise } \\
\text { Type }\end{array}$ & Industry Sector & $\begin{array}{c}\text { Franchisee } \\
\text { Experience } \\
\text { in Sector }\end{array}$ & $\begin{array}{l}\text { Previous } \\
\text { self- } \\
\text { employment }\end{array}$ & $\begin{array}{l}\text { Franchise } \\
\text { Network }\end{array}$ & $\begin{array}{l}\text { Franchisor } \\
\text { Country of } \\
\text { Origin }\end{array}$ & $\begin{array}{c}\text { Length of Time } \\
\text { Franchisee in } \\
\text { Operation }\end{array}$ & Contract Length \\
\hline $\mathrm{F} 1$ & single & Retail (F\&B) & Yes & No & International & Taiwan & $<6$ months & 3 years \\
\hline $\mathrm{F} 2$ & master & Retail (F\&B) & No & No & International & Taiwan & $<6$ months & 5 years \\
\hline F3 & single & Restaurant & Yes & Yes & International & Taiwan & 1.5 years & 2 years \\
\hline $\mathrm{F} 4$ & master & Restaurant & No * & Yes & International & Taiwan & 2 years & Not specified \\
\hline F5 & master & Retail (F\&B) & No & No & International & Taiwan & 4 years & 8 years \\
\hline F6* & Multi & Retail (F\&B) & No & No & International & Taiwan & 1 year & 3 years \\
\hline F7 & master & Retail $(\mathrm{F} \& \mathrm{~B})$ & No & Yes & International & Japan & $<6$ months & 5 years \\
\hline F8* & Multi & Professional Services & Yes & Yes & International & USA & 12 years & 3 years \\
\hline F9 & Master*** & Restaurant & No & Yes & Domestic & China & 3.5 years & 5 years \\
\hline $\mathrm{F} 10$ & master & Restaurant & Yes & No & Domestic & China & 3 years & 10 years \\
\hline F11 & single & Restaurant & No & No & International & Taiwan & 1.25 years & 3 years \\
\hline F12 & master & Restaurant & No & No & International & USA & 25 years & 20 years \\
\hline F13 & single & Retail (F\&B) & No & No & International & Taiwan & 3 years & Not specified \\
\hline F14 & master & Retail & No & Yes & International & USA & 6 years & 10 years \\
\hline $\mathrm{F} 15$ & master & Retail (F\&B) & Yes & Yes & International & USA & 1 year & 10 years \\
\hline F16 & single & Retail & No & No & Domestic & Hong Kong & 6 months & 3 years \\
\hline F17 & single & Professional Services & No & No & International & Australia & 6 months & 2 years \\
\hline F18 & master & Professional services & No & Yes & International & Germany & 3 years & 10 years \\
\hline F19 & master & Retail $(\mathrm{F} \& \mathrm{~B})$ & No & No & International & Taiwan & 1 year & 3 years \\
\hline $\mathrm{F} 20$ & single & Professional Services & No & No & Domestic & Macau & 1 year & Not specified \\
\hline $\mathrm{F} 21$ & single & Retail & No & Yes & International & Malaysia & 8 months & Renewed annually \\
\hline $\mathrm{F} 22$ & single & Retail & Yes & Yes & International & Malaysia & 6 months & Not specified \\
\hline $\mathrm{F} 23$ & single & Restaurant & No & No & Domestic & China & 6 months & 3 years \\
\hline
\end{tabular}

* This franchisee has franchise experience but within a different industry sector

** These franchisees have multiple units but each unit operates on a separate contract and there are no territorial rights allotted to these franchisees

***This franchisee started with a single-unit franchise 
Table 2: Memo for Thematic Coding: 'Opportunity Identification'

\section{Question asked of the data}

Q1 How were informants first alerted to the opportunity to start their business?

Q2 Can they be categorised in any way in relation to their cause or source?

Q3 What research activities did informants undertake in the opportunity search process?

Q4 What data sources did they use in the search process?

Q5 Why were these data sources used?

Q6 Do the answers to these questions differ according to the informant backgrounds?

Q7 How do these answers (if at all) differ across the informant backgrounds?

\section{Appendix 1: Interview Guide}

Explanation of the aim of the research

Part One: Background Information

Type of franchise agreement

Service industry sector

Franchisor Identifier Code (name to be kept confidential)

Franchisor Network (Domestic or International)

Length of Time Franchise

Length of Franchise Contractual Agreement

Part Two: Identifying Opportunities

Explanation of how identified opportunity

Information sources used

Activities undertaken

Factors that influenced decisions made

Overview of the process

Part Three Evaluating Opportunities:

Explanation of the evaluation process

Criteria used to evaluate opportunity

Activities undertaken to gather information for evaluation purposes

Information sources used

How and when criteria used during the process

Factors that influenced decision made

Part Four: Additional Comments

Additional comments

Reflections on the process 